\title{
Investigating the Organizational Citizenship Behaviours of Hotel Business Employees through Structural Equation Modelling: A Study in Rize Province
}

\author{
Ali Çağlar Güllüce¹, Eren Erkiliç² \\ ${ }^{1}$ Open Education Faculty, Atatürk University, Erzurum, Turkey \\ ${ }^{2}$ Ardeşen Vocational School, Recep Tayyip Erdoğan University, Rize, Turkey \\ Email: alichaglar@yahoo.com
}

Received 12 January 2015; accepted 24 March 2015; published 27 March 2015

Copyright (C) 2015 by authors and Scientific Research Publishing Inc.

This work is licensed under the Creative Commons Attribution International License (CC BY). http://creativecommons.org/licenses/by/4.0/

\section{(c) (;) Open Access}

\begin{abstract}
The aim of this research is to identify organizational citizenship behaviours of employees working in hotels operating in Rize. To this end, a questionnaire was applied to 228 employees working in these hotels. The gathered data were analysed with LISREL program. Positive significant differences were found between factors of organizational citizenship behaviours as a result of confirmatory factor analysis which was carried out to identify research participants' organizational citizenship behaviours. It is identified that the most effective variables on Altruism factor by 0.87 are "I help an employee learn the tasks who has just started the job" and "I do not refrain from sharing materials I have with the business employees for work related problems"; the most effective variable on conscientiousness factor by 0.84 is "I want to participate in all activities that create positive image for my organization"; the most effective variable on courtesy factor by 0.88 is "I warn other employees not be harmed when unexpected problems arise"; the most effective variable on sportsmanship factor by 0.68 is "I take active role in the resolution of conflicts occurring in my organization"; and the most effective variable on civic virtue factor by 0.86 is "I keep up with changes in the structure of my organization". In addition, conscientiousness factor and sportsmanship factor have an effect of 0.99 between each other.
\end{abstract}

\section{Keywords}

Organizational Citizenship, Structural Equation, LISREL 


\section{Concept of Organizational Citizenship Behaviour}

In a competitive environment, that hotel businesses can operate in required conditions depends on employees' displaying extra role behaviours which are beyond their role descriptions. Such behaviours are stated as organizational citizenship behaviours in businesses (Aslan, 2009: p. 270). Considering that there is a difference between voluntary behaviours and official job descriptions, Organ found out in 1988 that organizational citizenship behaviours are extra role behaviours that are beyond mandatory job descriptions (Organ, 1997: p. 87). Therefore Organ (1998) defined organizational citizenship behaviours as voluntary behaviours which are beyond contract of employment formed between employee and organization and agreed upon job descriptions, and these behaviours are not directly or overtly stated by official reward system for individual behaviours but they are formed through incentives that are effective in carrying out operations of organization efficiently. George and Brief (1992) stated organizational citizenship behaviours as behaviours that are within or beyond employees' role descriptions and that are outside the formal reward system. Greenberg and Baron defined organizational citizenship behaviour concept as an employee's extending beyond obligations determined formally by the organization and carrying out more than what is required (Greenberg \& Baron, 2000: p. 372). Extra role behaviours are not significant in meeting job requirements and executives do not expect them to be performed. These behaviours strengthen social structure of the organization but they do not directly affect task performance. For example, behaviours such as supporting co-workers in a job related problem, helping in maintaining the work place clean and neat, making on time and constructive suggestions about the work to executives and preserving organizational sources can be considered within this framework (Taşçı \& Koç, 2007: p. 374).

It can be asserted that organizational citizenship behaviour forms the informal part of the organization or the invisible part of the iceberg; however, when considered as a whole, it is one of the social facts that can contribute to efficiency of the organization (Gürbüz, 2006: p. 50). In this sense, the common point of the definitions of organizational citizenship behaviour is that these behaviours are considered as extra role behaviours in the organization which are displayed based on willingness and voluntariness principles and they contribute to organizational effectiveness (Sezgin, 2005: p. 319).

\subsection{Development of Organizational Citizenship Behaviour Concept}

It is possible to associate the appearance of "organizational citizenship behaviour” as a concept in literature within the context of studies on organizational behaviour with the studies which started in 1930's and is still going on as a process. Organizational citizenship behaviour, which appeared in 1980's as an independent concept, has become the centre of attention nowadays. It is possible to assess conceptualization process of organizational citizenship behaviour within two different time periods. The first of these is between 1930 and 1980 when there were basic studies contributing to conceptualization and the second one is the period from 1980's, when organizational citizenship behaviour started as an independent concept, until today when comprehensive studies on this issue still continue (Karaaslan et al., 2009: p. 137).

When the studies before 1980's are examined, it can be seen that there weren't any empirical research which studied particularly organizational citizenship behaviour. Yet, in some studies in the past years in which opinions as to informal organizations took place, there were some concepts that would form the basis for organizational citizenship behaviour in the following years (İşbaş1, 2000: p. 6). Bernard's studies take place on the top of the studies that created research and contributed for the definition of organizational citizenship behaviour (Gök, 2007: p. 58). Besides, Katz and Kahn stated that system rewards couldn’t motivate employees towards increasing their role performances in the business; however, they accepted the possibility that these rewards could increase the degree of relationships towards cooperation among employees. For this case to happen, the employees need to consider the allotment of system rewards as fair and sharing shouldn't create invidious differences among individuals and groups. Katz and Kahn express that individual differences are considered solely on the basis of employees' income and citizenship concept is not addressed at this point. Civic sensitivity represents the contribution that employees working in organizations can provide beyond following through obligations based on contract of employment, which is similar to a good citizen's contribution to his/her country beyond only obeying the laws. Yet it is possible for people to be able to behave like a citizen only if they feel that they are treated as a citizen (Organ, 1988, cited in İşbaş1, 2000: p. 12). Therefore, it can be suggested that dimensions of organizational citizenship behaviour regarding to what extent citizenship behaviour is effective vary by employees' setting and business in which they work depending on their personal characteristics. 


\subsection{Dimensions of Organizational Citizenship Behaviour}

Organ (1988 cited in Arslantaş \& Pekdemir, 2007: p. 264) listed organizational citizenship behaviour in five different dimensions which are altruism, conscientiousness, courtesy, sportsmanship and civic virtue. Organizational citizenship behaviour is examined in these five dimensions as Organ's dimensioning is the most common one in the literature.

\subsubsection{Altruism}

The altruism dimension of organizational citizenship behaviour relates to helping a worker who has difficulty in doing a task or fails in succeeding doing it (Sezgin, 2005: p. 323). Organ (1988) assesses the behaviour of helping others with self-sacrifice, reconciliation and cheerleading dimensions. It is stated as helping co-workers in order to prevent problems in advance (Podsakoff, 2000: p. 517). The opinion that a helping individual is a good citizen is prevalent. With this respect, cooperation will increase the ratio of knowledge sharing and knowledge acquisition. Besides, organizational citizenship behaviour requires caring about organization, standing by organization and doing several extra sacrifices for the organization when necessary. It gets easier for the organization to reach its aims as responsibility feeling develops among employees. Employees' use of authority in a certain responsibility framework eases managers’ supervision and increases individual self-control (Özdevecioğlu, 2003: p. 119).

\subsubsection{Conscientiousness}

Conscientiousness is an employee's voluntary behaviours beyond his/her minimum role requirements in obeying rules and regulations, taking break and so on (Podsakoff et al., 1990: p. 115). The word conscientiousness is defined as a force which prompts an individual to make judgement about his/her behaviours and enables the individual to make direct and instinctive judgements about his/her own moral values (Turkish Language Institute, 2014). These behaviours may include arriving work early, leaving late; abstaining from long and unnecessary breaks; being punctual in meetings and appointments; completing duties in time; preserving company resources, making constructive suggestions (Özyer et al, 2012: p. 183). Furthermore, being punctual, using tea, coffee and meal breaks carefully, attending regularly to meetings in organizations and obeying all formal and informal rules that are developed to maintain order in the organization are also examples of conscientiousness behaviour (İşbaş1, 2000: p. 26).

\subsubsection{Courtesy}

These are voluntary behaviours aimed at preventing problems related to the work in advance (MacKenzie et al., 1993: p. 71). According to Organ and Ryan (1995: p. 782), courtesy is a sportsmanship behaviour which shows abstaining from little and temporary personal faults without disorder, objection and protest in organization, and it is a behaviour of taking measures by foreseeing co-workers' problems and helping them. In administration, courtesy refers to positive communication among individuals that are connected mutually to each other due to division of labour in the organization (Özdevecioğlu, 2003: p. 121).

\subsubsection{Sportsmanship}

It means tolerating any kind of unfavourable things that may create tension among individuals in organization (Özdevecioğlu, 2003: p. 121). In other words, it includes behaviours such as tolerating towards inevitable disturbance and compulsion caused by the work, not complaining because of being disturbed by others, maintaining positive attitudes when things do not go well, not being annoyed when others have different opinions, sacrificing for a good group work, respecting others' thoughts. Almost every organization setting has inevitable challenges. A sportsman person puts up with these gladly and does not overstate unimportant issues (Organ \& Ryan, 1995; Köse et al., 2003, cited in Bolat et al., 2009: p. 218). According to Organ (1998), behaviours in this dimension include respecting co-workers, not overstating problems unnecessarily, seeing positive sides of things as opposed to negative sides, having a constructive attitude towards problems about organizations, defending image and activities of the organization in different settings (Gürbüz, 2006: p. 56).

\subsubsection{Civic Virtue}

Civic virtue refers to commitment to an organization as a whole and interest in macro level. This dimension 
means doing voluntary behaviours like participating actively in administration such as stating ideas as to strategies regarding the organization and attending meetings, following environmental threats and opportunities that may affect the organization, reporting fire hazards and suspicious activities, having an external perspective for realizing the best aspects (Podsakoff et al., 2000: p. 525).

\subsection{Determinants of Organizational Citizenship Behaviour}

Concepts that form the basis of organizational citizenship behaviour are examined in four groups which are characterristics of employee, characteristics of work, organizational characteristics and leader's behaviours (Podsakoff et al., 2000: p. 526).

Characteristics of employee: The first factor in employee's characteristics is morale factor. Organ and Ryan (1995) defend that in addition to morale factor, interrelated variables such as compatibility, positive emotionality, and negative emotionality may tend to comply with individuals' co-workers and administrators. It is stated that individuals' satisfactory, supportive, fairness and loyalty behaviours may increase. Hence, it is observed that although these variables do not directly result in organizational citizenship behaviour, they indirectly affect it (Podsakoff et al., 2000: p. 530).

Characteristics of work: That a work piece provides feedback and autonomy enables employees to monitor their own behaviours and develop personal control feeling (Alp, 2007: p. 87).

Organizational Characteristics: It is identified that there is a positive relationship between group solidarity variable and five dimensions of organizational citizenship behaviour which are altruism, conscientiousness, courtesy, sportsmanship and civic virtue. It is determined that organizational support variable is significantly related with worker sacrifice. Besides, it is found out that awards beyond leader's control variable have an inverse relationship with altruism, courtesy and conscientiousness (Podsakoff, 2000: p. 531). Furthermore, organizational characteristics include "organizational fairness”, “organizational commitment”, "attitudes towards work and work satisfaction”, seniority and hierarchy”, organizational vision”, “participation in decisions”, and “organizational identification” factors and these factors affect organizational citizenship behaviour (Keleş, 2009: pp. 30-35).

Leadership behaviours: How the leaders should manage in order to develop organizational citizenship behaviour and how they should encourage relationship are significant issues. Leaders need to accept that employees display positive social work behaviours for their organizations. Because of the nature of organizational citizenship behaviour, there are not many employees who volunteer to do their best in terms of extra role behaviours while carrying out the necessities of the work in order to be helpful to their organization, superiors and coworkers. The leaders' capability to motivate employees relying on a formal award system in order to reinforce extra role behaviours is also limited (Schappe, 1998: p. 288).

\section{Material and Method}

\section{Structural Equation Modelling}

Structural Equation Modeling is a statistical method that is able to define the cause and effect relationship of the variables among the composite hypotheses. It is also an effective method to help test and develop models along with testing the hypothetical models as a whole. In addition, SEM models provide the practitioners with an opportunity to specify the direct and indirect effects among variables. Besides, SEM is a multivariate statistical approach that is capable of modeling by incorporating the interaction among the hypothetical structures, measurement error of the structures and the relationships among the errors. SEM is also known as the simultaneous equation or multivariate regression models (Bollen, 1989; Fox, 2006; SchumackerandLomax, 2004; Kline, 2005).

Structural equation modelling (SEM) is a comprehensive statistical technique used in testing the relations of causality between observable and latent variables. It is also proven that it is a useful technique in the solution of problems faced when formulating theoretical structures. It is a systematic tool used in testing theoretical models and evaluating relationships among variables particularly in psychology, sociology, marketing and educational sciences. Technically SEM is used in prediction of unknown parameters in structure equation set. Variables in equations are generally latent variables that are in relationship with directly observed variables. SEM assumes that there is a causality structure among latent variables set and latent variables can be measured through observable variables (Y1lmaz \& Çelik, 2005). 
SEM is a statistical modelling technique and sets forth reason-result relation among measured and unmeasured variables. SEM is more robust than many analysis techniques such as multiple regression, path analysis, factor analysis, time-series analysis and covariance analysis and includes methods as alternative to these methods (Şehribanoğlu, 2005).

SEM includes one or more linear regression equations describing how inner structures are tied to outer structures. Its coefficients are called path coefficients or mostly regression measurement. SEM follows the following steps:

1) Developing a theoretical model,

2) Drawing a diagram displaying relations of causality for the developed model,

3) Transforming the diagram to structural and measuring models,

4) Predicting and evaluating the structural.

5) Calculating compliance standards of structural modelling,

6) Interpreting the results (Şahin, et al., 2008).

As seen in Table 1, the package programs used in SEM analysis gives different amounts of fit indices and sometimes the same index is given under a different name. LISREL users generally interpret results according to fit indices such as GFI, AGFI, RMSEA, CFI and NNFI as well as chi square value (Sümer, 2000).

\section{Research Application}

To measure organizational citizenship, the scale which was adapted from Vey/Campbell (2004) and Williams/ Shiaw's (1999) studies by Basım and Şeşen in 2006 was used. The reason for using two studies was to combine strengths of two scales which are put forth through statistical data and form an effective scale. In addition, it is stated that the questionnaire consists of five main dimensions and it complies with organizational citizenship behaviour dimension suggested by Organ (1988). Organizational Citizenship Scale includes 19 questions in order to measure altruism (5 items), conscientiousness (3 items), courtesy (3 items), sportsmanship (4 items) and civic virtue (4 items).

280 employees who were randomly selected among employees of hotels operating in Rize in 2014 took the questionnaire form. Sample size was calculated via $n=\sigma^{2} Z_{\alpha}^{2} / H^{2}$ formula which is recommended for infinite populations ( $\mathrm{N}>10,000)$ and quantitative studies by Özdamar (2001). Questionnaire is 5 point Likert type (1. I certainly disagree, 5 I certainly agree). Questionnaire forms that were improper or not complete were eliminated and 228 valid questionnaire forms were analysed.

Reliability coefficient Cronbach's Alpha value for the items in the overall questionnaire was calculated as 0.949 and this proves that questionnaire is highly reliable.

$40.4 \%$ of research participants are male and 59.6\% are female. According to Table 2, 9.2\% of employees are under the age of 20, 29.8\% are between the ages of 21 - 25, 24.1\% are between the ages of $26-30$ and $36.8 \%$ are over the age of $30.18 \%$ of the employees are elementary school graduates, $44.3 \%$ are high school graduates, $35.5 \%$ are university graduates and $2.2 \%$ have master's degree. 50.9\% of participants are married and $47.4 \%$ are single.

34.2\% of participants work in front desk department, 31.1\% work in food-beverages department, 21.9\% work in housekeeping department, 6.6\% work in sales marketing department and 6.1\% work in accounting department. Besides, 31.1\% of participants have been working for less than a year, 43\% have been working for 1 - 5 years, $15.8 \%$ have been working for 6 - 10 years and 10.1\% have been working for more than 10 years in hotel businesses.

In Figure 1, the relationships between five factors in the organizational citizenship behaviour and their variables, and relationships among factors are given.

In Figure 1, ÖD refers to "Altruism” dimension of organizational behaviour; ÖV refers to "Conscientiousness”; ÖN refers to “Courtesy”, ÖC refers to “Sportsmanship”, and ÖS refer to “Civic Virtue”. Besides, ÖD1, ÖD2, ÖD3, ÖD4, ÖD5 refer to variables of altruism dimension; ÖV1, ÖV2, ÖV3 refer to variables of conscientiousness dimension; ÖN1, ÖN2, ÖN3 refer to variables of courtesy; ÖC1, ÖC2, ÖC3, ÖC4 refers to variables of sportsmanship, and ÖS1, ÖS2, ÖS3, ÖS4 refer to variables of civic virtue.

In this regard, it is seen in Figure 1 that an increase of one unit in ÖD1 "I do daily tasks of an employee who is on leave for a day" variable has a positive effect of 0.50 on (ÖD) altruism dimension. An increase of one unit in ÖD3 “I help an employee learn the tasks who has just started the job” variable has a positive effect of 0.87 on 
Table 1. Values of compliance standards for the model.

\begin{tabular}{cccc}
\hline Compliance Standards & Perfect Compliance & Acceptable Compliance & Model \\
\hline RMSEA & $0<$ RMSEA $<0.05$ & $0.05 \leq \mathrm{RMSEA} \leq 0.10$ & $\mathbf{0 . 0 6 1}$ \\
NFI & $0.95 \leq \mathrm{NFI} \leq 1$ & $0.90<\mathrm{NFI} \leq 0.95$ & $\mathbf{0 . 9 8 0}$ \\
NNFI & $0.97 \leq \mathrm{NNFI} \leq 1$ & $0.95 \leq \mathrm{NNFI} \leq 0.97$ & $\mathbf{0 . 9 9 0}$ \\
CFI & $0.97 \leq \mathrm{CFI} \leq 1$ & $0.95 \leq \mathrm{CFI} \leq 0.97$ & $\mathbf{0 . 9 9 0}$ \\
GFI & $0.95 \leq \mathrm{GFI} \leq 1$ & $0.90 \leq \mathrm{GFI} \leq 0.95$ & $\mathbf{0 . 9 0 0}$ \\
AGFI & $0.90 \leq \mathrm{AGFI} \leq 1$ & $0.85 \leq \mathrm{AGFI} \leq 0.90$ & $\mathbf{0 . 8 5 0}$ \\
\hline
\end{tabular}

Source: Schermelleh-Engel and Moosbrugger, 2003: p. 36.

Table 2. Hotel employees’ demographic characteristics.

\begin{tabular}{|c|c|c|c|}
\hline Factor & Category & Frequency & Percentage \\
\hline \multirow{2}{*}{ Gender } & Male & 92 & 40.4 \\
\hline & Female & 136 & 59.6 \\
\hline \multirow{4}{*}{ Age } & Under 20 & 21 & 9.2 \\
\hline & $21-25$ & 68 & 29.8 \\
\hline & $26-30$ & 55 & 24.1 \\
\hline & Over 30 & 84 & 36.8 \\
\hline \multirow{4}{*}{ Education } & Primary school & 41 & 18.0 \\
\hline & Secondary school & 101 & 44.3 \\
\hline & Faculty & 81 & 35.5 \\
\hline & Master's Degree & 5 & 2.2 \\
\hline \multirow{3}{*}{ Marital Status } & Married & 116 & 50.9 \\
\hline & Single & 108 & 47.4 \\
\hline & Other & 4 & 1.8 \\
\hline \multirow{5}{*}{ Department } & Front desk & 78 & 34.2 \\
\hline & Food-Beverages & 71 & 31.1 \\
\hline & Housekeeping & 50 & 21.9 \\
\hline & Sales Marketing & 15 & 6.6 \\
\hline & Accounting & 14 & 6.1 \\
\hline \multirow{4}{*}{ Duration of Working } & Less than 1 year & 71 & 31.1 \\
\hline & 1 - 5 years & 98 & 43.0 \\
\hline & 6 - 10 years & 36 & 15.8 \\
\hline & More than 10 years & 23 & 10.1 \\
\hline
\end{tabular}

(ÖD) altruism dimension. In addition, an increase of one unit in ÖD4 "I do not refrain from sharing materials I have with the business employees for work related problems" variable has a positive effect of 0.87 on altruism dimension as in ÖD3.

Güler (2013) suggests that the variable of "I help an employee learn the tasks who has just started the job" in altruism dimension has the highest effect. In this respect, comparing hotel businesses with their employees it can be suggested that a new employee who has just started is provided with a kind of orientation training to learn the tasks by the other personnel working there whatever their department is as these businesses are complex businesses in themselves. 
On the other hand, an increase of one unit in ÖV2 "I want to participate in all activities that create positive image for my organization" variable has a positive effect of 0.84 on (ÖV) conscientiousness dimension and an increase of one unit in ÖV3 "I do not spend time for my personal affairs in working hours" variable has a positive effect of 0.46 .

It is identified in Sökmen and Boylu's (2011) study that the effect particularly in conscientiousness dimension is higher. It is stated that in the hotel businesses where the study took place, the employees were sensitive to regularity, neatness and punctuality issues and have positive attitudes. It can be suggested in this study that feeling that participating to activities in favour of their organization honours both the workplace and themselves and not spending time for personal affairs in working hours are among findings.

As given in Figure 1, ÖN1 “I respect other employees' rights” variable has a positive effect of 0.86 on (ÖN) courtesy dimension while ÖN2 "I warn other employees not be harmed when unexpected problems arise" variable has an effect of 0.88 and an increase of one unit in ÖN3 "I try not to create problems for people I work together" variable has a positive effect of 0.85 .

Alioğulları (2012) puts forth that "respecting co-workers" and "not creating problems for co-workers" variables have higher effect in Courtesy dimension and this situation affects employees' thoughts towards their co-workers and the harmony among them. As is seen, hotel business employees' respecting each other's rights and being directive and self-sacrificing are highly effective in courtesy dimension.

In sportsmanship dimension of organizational behaviour, an increase of one unit in ÖC1 "I do not waste time by complaining about unimportant problems" variable has an effect of 0.65 ; ÖC2 "I try to see positive aspects rather than focusing on problems in working place" variable has an effect of 0.57; ÖC3 "I do not feel offended or angry about new situations I undergo at work" variable has an effect of 0.56 and ÖC4 "I take active role in the resolution of conflicts occurring in my organization" variable has a positive effect of 0.68 .

Karaaslan, Ergun Özler and Kulaklıoğlu (2009) indicate that employees' continuing to make positive suggestions to contribute positively to organization without feeling offended to ones that do not support their personal opinions and suggestions and that react to them, which is among samples of behaviours in sportsmanship dimension, can also be considered as knowledge sharing behaviour. According to results above, the facts that

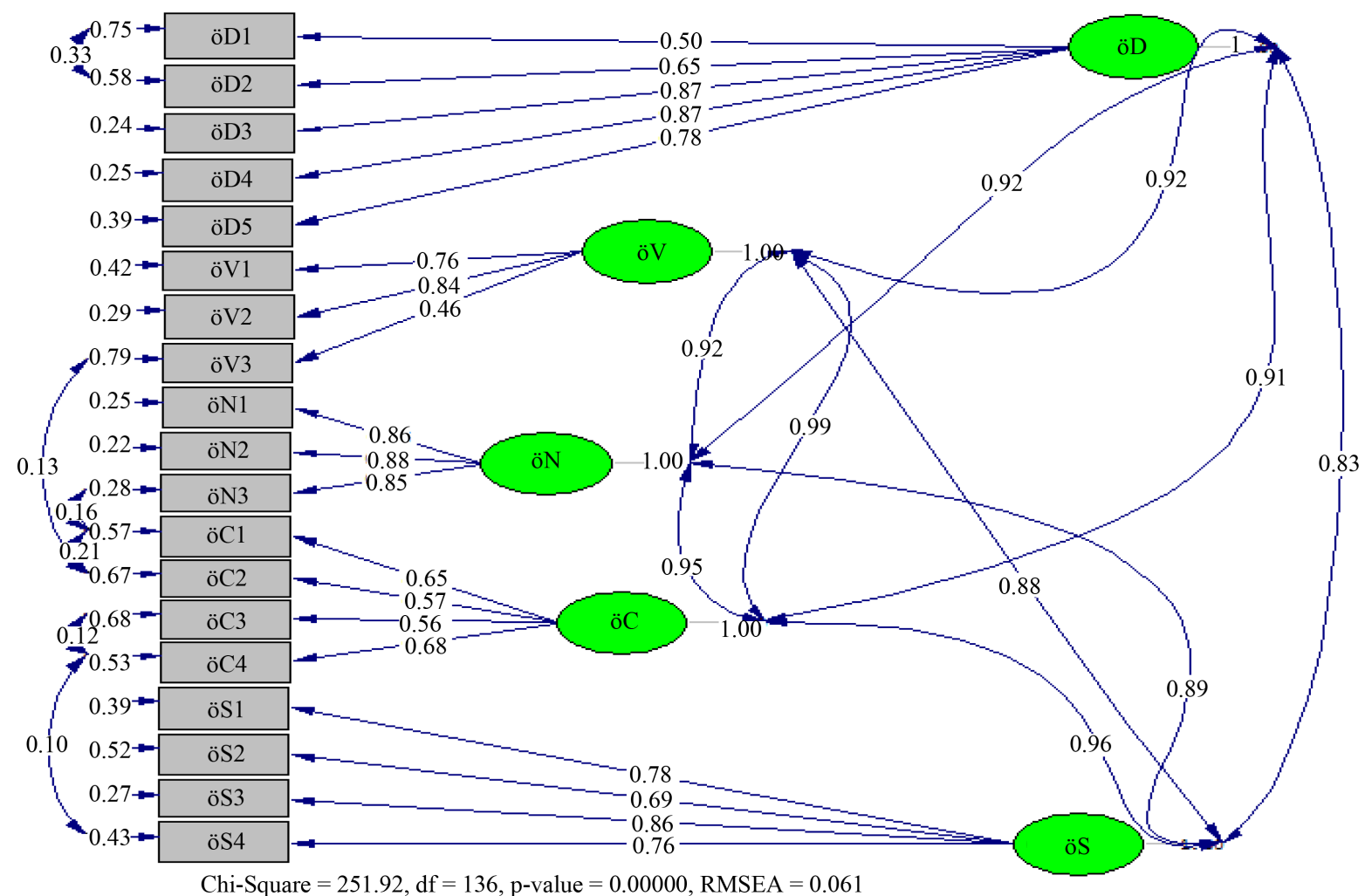

Figure 1. Results of confirmatory factor analysis showing hotel employees’ organizational citizenship statuses. 
employees do not waste their time on unimportant problems, they want to see positive aspects rather than negative aspects of problems and they want to take active role in the resolution of conflicts can be represented as awareness of the ability to maintain their work in a peaceful and quality setting.

An increase of one unit in ÖS2 “I voluntarily participate to social activities of my organization” variable has a positive effect of 0.69 on (ÖS) civic virtue while ÖS3 “I keep up with changes in the structure of my organization" variable has an effect of 0.86 .

"I keep up with changes in the structure of my organization" variable has the highest average in civic virtue dimension in Kalkan's (2013) study, and similarly it is seen that this variable is the most effective variable in civic virtue dimension in this study. Hotel businesses are in an obligation to stand out among their rivals in accordance with modern administration approaches and technology, and therefore labour intensive hotel businesses primarily need to ensure employees’ participation and acceptance.

Analysing the relationship among dimensions of organizational citizenship behaviour it is determined that regarding the relationship between (ÖD) altruism and (ÖV) conscientiousness dimensions, an increase of one unit in both dimensions has a positive effect of 0.92 on both of them. Regarding the relationship between (ÖD) altruism and (ÖN) courtesy dimensions, an increase of one unit in both dimensions has a positive effect of 0.92 on both of them. Regarding the relationship between (ÖD) altruism and (ÖC) sportsmanship dimensions, an increase of one unit in both dimensions has a positive effect of 0.91 on both of them. Regarding the relationship between (ÖD) altruism and (ÖS) Civic Virtue dimensions, an increase of one unit in both dimensions has a positive effect of 0.83 on both of them.

Aksoy (2010) separately examined dimensions of organizational citizenship behaviour and put forth that the majority of employees tend to display organizational citizenship behaviour. Baran (2002) stated that organizational citizenship behaviour is mainly carried out voluntarily by members of the organization. Waris (2005) suggested that organizational citizenship behaviours are performed without a formal demand from the organization and Aras (2010) set forth that these behaviours are not obligatory in job descriptions; they do not necessitate a punishment in case of negligence; they are performed as a result of personal preference. Examining the relationship of altruism dimension with other dimensions, it is seen that it affects all other dimensions positively. Hence, it is possible to suggest that situations such as doing daily tasks of an employee who is on leave for a day, helping co-workers doing the same task, sharing materials they affect all other dimensions of organizational citizenship behaviour positively. In addition, that employees voluntarily contribute to this situation supports previously examined studies.

Regarding the relationship of (ÖV) conscientiousness dimension with (ÖN) courtesy dimension, an increase of one unit in both dimensions has a positive effect of 0.92; regarding the relationship of (ÖV) conscientiousness dimension with (ÖC) sportsmanship dimension, an increase of one unit in both dimensions has a positive effect of 0.99, and regarding the relationship of (ÖV) conscientiousness dimension with (ÖS) civic virtue dimension, an increase of one unit in both dimensions has a positive effect of 0.88 . Therefore, it is possible to argue that employees' spending most of their time on work related activities, volunteering to participate in activities that create positive image for their organization and not wasting time on personal affairs affect all other dimensions of organizational citizenship behaviour positively.

Regarding the relationship of (ÖN) courtesy dimension with (ÖC) sportsmanship dimension, an increase of one unit in both dimensions has a positive effect of 0.95 ; regarding the relationship of (ÖN) courtesy dimension with (ÖC) civic virtue dimension, an increase of one unit in both dimensions has a positive effect of 0.89 . Finally, regarding the relationship of (ÖS) sportsmanship dimension with (ÖS) civic virtue dimension, an increase of one unit in both dimensions has a positive effect of 0.96 between the two.

The results suggest that, as put forth in Organ (1998), organizational citizenship behaviour is a personal behaviour relying on voluntariness which is not directly and completely taken into consideration in formal system but which helps increase the efficiency of the organization as a whole; and analysis of relationships among factors in the study reveals that they support each other.

\section{Conclusion and Recommendations}

Today, human resource is the most significant factor for effective and efficient hotel businesses (Buluç, 1995). Albeit new technologies, new insights arise in marketing, it is people who will implement these. An organization with a strong human resource has a big advantage against its rivals. From this perspective, the importance 
of organizational citizenship behaviour emerges which is not present in formal job descriptions and which is performed voluntarily by the employees. Considering the labour intensive characteristics of tourism, it can be argued that service quality can be enhanced only through employees who do not differentiate organization's gains from their own gains and who become integrated with their organization (Keleş \& Pelit, 2009: p. 25).

This study has reached similar results with the recent studies on organizational citizenship behaviour. It is revealed and accepted that organizational citizenship behaviour affects administrators and employees of hotels positively.

Analysing the relationships among dimensions of organizational citizenship behaviour, it is indicated that the relationships among all dimensions are positive and have a high degree. Organizational citizenship behaviour is important because hotel businesses depend on crew management; therefore, it makes altruism essential as a dimension. It is put forth in the study that helping voluntarily to new starters, getting them accustomed to work, substituting for co-workers when they are on leave, sharing their materials with their co-workers and making time for each other are important factors in the increment of success in hotel businesses.

It is revealed in the study that hotel employees' perceptions of organizational citizenship behaviour are positive. When required working setting and conditions are provided, the employees seem to be ready for contributing to aims of hotel businesses. Therefore, there are things to do in order to provide opportunities for employees to use their capacities at the highest level, to solve problems, determine policies regarding working environment, make decisions and create a positive working environment where all employees are included in service.

Organizational citizenship behaviour is a voluntary personal behaviour which does not directly or clearly appear in formal award system and which increases efficiency of an organization as a whole. Organizational citizenship behaviours include behaviours that do not rely on giving orders, that provide organizational gains, that are not formal and that reduce undesirable behaviours such as complaining as well as behaviours such as finishing tasks on time, being innovative and voluntarily helping co-workers (Ünüvar, 2006: p. 177). The significance of organizational citizenship behaviour becomes apparent considering that the most important factor in hotel businesses is customer satisfaction. A good organizational citizen is satisfied with the job, gets motivated, becomes integrated with the organization, and increases effectiveness (Yeşiltaş \& Keleş, 2009: p. 33).

The overall study shows that employees in hotel businesses are self-sacrificing, helpful, committed to business from the aspect of sense of belonging, protective, participative, awareness, guiding, courteous and reflect organizational citizenship behaviour to their working place at a high level.

It is natural that this study may have some restrictions and weak aspects. However, it fills an important gap in the literature as it examines sub dimensions of organizational citizenship behaviour. Similar future research on this issue with different samples may be fruitful. Similar studies on different sectors may help us better understand organizational citizenship behaviour and by this means it may provide opportunities to follow strategies that may change employees' behaviours positively.

\section{References}

Aksoy, E. Ş. (2010). Iş̧yerlerinde Mobingile Örgütsel Vatandaşşlık Davranışı Arasıındaki İlişkinin Incelenmesine Yönelik Bir Araştırma. Kütahya: Dumlupınar Üiversitesi, SosyalBilimlerEnstitüsü, İşletme Anabilim Dalı.

Alioğulları, Z. D. (2012). Örgütsel Sessizlik VeÖrgütsel Vatandaşlık Davranışı Arasındaki Ilişki: Biruygulama. Erzurum: Atatürk Üniversitesi.

Alp, M. (2007). Örgütlerde Psikolojik Sahiplenmeve Örgütsel Vatandaşlık (Yayınlanmamış YL Tezi). Kütahya: Dumlupınar Üniversitesi.

Aras, M. (2010). Örgütsel Bağlllık; GOÜ Akademik Personeli Üzerine Bir Uygulama, Yayınlanmamış Yükseklisans Tezi. Tokat: Gazi Osman Paşaüniversitesi, Sosyal Bilimler Enstitüsü.

Arslantaş, C., \& Vepekdemir, C. I. (2007). Dönüşümcü Liderlik, Örgütsel Vatandaşlık Davranışı Ve Örgütsel Adalet Arasındaki İlişkileri Belirlemeyeyönelik Görgül Bir Araştırma. Sosyal Bilimler Dergisi, 1, 261-286.

Aslan, G. (2009). Karizmatik Liderlikve Örgütsel Vatandaşlık Davranışı İlişkisis: "Kurumda Çalışma Yılı" ve "Ücret”" Değişkenlerinin Rolü. Uluslararası İnsan Bilimleri Dergisi, 6, 256-275.

Baran, M. (2002). İşletmelerde Bilginin Yönetilmesi Ile Ilgili Olarak Geliştirilen Modeller Ve Bir Araştırma. İstanbul: İstanbul Üniversitesi SBE, Yayımlanmamış Doktora Tezi.

Basım, N., \& Şeşen, H. H. (2006). Örgütsel Vatandaşlık Davranışı Ölçeği Uyarlamave Karşılaştırma Çalışması. Ankara Üniversitesi Siyasi Bilimler Fakültesi Dergisi, 61, 83-101. 
Bolat, İ., Bolat, O. T., \& Seymen, A. O. (2009). Güçlendirici Lider Davranışlarıve Örgütsel Vatandaşlık Davranışı Arasındakiİlişkinin Sosyal Mübadele Kuramından Hareketle İncelenmesi. Balıkesir Üniversitesi Sosyal Bilimler Enstitüsü Dergisi, 12, 215-239.

Buluç, G. (1995). Turistik Belgeli Konaklama Işsletmelerinde Personel Seçimi Politikaları Üzerine Bir Çalışma. Turizmde Seçme Makaleler: 22, TUGEV No: 34, 39-53.

George, J. M., \& Brief, A. P. (1992). Feeling Good-Doing Good: A Conceptual Analysis of the Mood at Work-Organizational Spontaneity Relationship. Psychological Bulletin, 112, 310-329. http://dx.doi.org/10.1037/0033-2909.112.2.310

Greenberg, J., \& Baron, R. A. (2000). Behavior in Organizations (7th ed.). Upper Saddle River, NJ: Prentice-Hall.

Gök, E. E. (2007). Örgütsel Kültür Bağlamında Örgütsel Vatandaşlık Olgusu Ve Bir Araştırma. Yayınlanmamış Yüksek Lisans Tezi, Denizli: Pamukkale Üniversitesi.

Güler, N. (2013). Üniversite Çalışanlarında Örgütsel Vatandaşlık Davranışı: Gazi Üniversitesinde Bir Araştırma. Ankara: Gazi Üniversitesi.

Gürbüz, S. (2006). Örgütsel Vatandaşlık Davranışıile DuygusalBağl1lık Arasındaki İlişkilerin Belirlenmesine Yönelik Bir Araştırma. İstanbul Üniversitesi İktisadive İdari Bilimler Fakültesi Ekonomikve Sosyal Araştırmalar Dergisi, 3, 48-75.

İşbaşı, J. Ö. (2000). Çalışanların Yöneticilerine DuyduklarıGüveninve Örgütsel Adaleteİlişkin Algılamalarının ÖrgütselVatandaşlık Davranışının Oluşumundaki Rolü: Bir Turizm Örgütünde Uygulama. Yayınlanmamış Yükseklisans Tezi, Antalya: Akdeniz Üniversitesi.

Kalkan, A. (2013). Algılanan Örgüt Kültürünün Örgütsel Vatandaşlık Davranışı Üzerindeki Etkisi: Kuramsal Ve Görgül Bir Araştırma. Konya: Selçuk Üniversitesi.

Karaaslan, A., Özler, E. D., \& Vekulaklıŏglu, S. A. (2009). Örgütsel Vatandaşlık Davranışı Ve Bilgi Paylaşımı Arasındakiİlişkiye Yönelik Bir Araştırma. Afyon Kocatepe Üniversitesi İktisadi Veİdari Bilimler Fakültesi Dergisi, 1, $135-160$.

Keleş, Y. (2009). İşgörenlerin Eğitim Düzeylerinin Örgütsel Vatandaşlık Davranışına Etkisi. Yayınlanmamış Yüksek Lisans Tezi, Ankara: Gazi Üniversitesi.

Keleş, Y., \& Pelit, E. (2009). Otel Işletmesi Işgörenlerinin Örgütsel Vatandaşlık Davranışları: Istanbul'daki BeşYıldızlıOtel Işletmelerinde Bir Araştırma. Ekonomik Ve Sosyal Araştırmalar Dergisi, Güz 2009, 5, 24-45.

Köse, S., Kartal, B., \& VeKayalı, N. (2003). Örgütsel Vatandaşlık Davranışı ve Tutuma İlişkin Faktörlerle İlişkisi Üzerine Bir Araştırma. Erciyes Üniversitesi İktisadive İdari Bilimler Fakültesi Dergisi, 20, Ocak-Haziran, 1-19.

MacKenzie, S. B., Podsakoff, P. M., \& Fetter, R. (1993). The Impact of Organizational Citizenship Behavior on Evaluations of Salaesperson Performance. Journal of Marketing, 57, 70-80. http://dx.doi.org/10.2307/1252058

Organ, D. W. (1988). Organizational Citizenship Behavior: The Good Soldier Syndrome. Lexington, England: Lexington Books.

Organ, D. W. (1997). Organizational Citizenship Behavior: It’s Construct Clean-Up Time. Human Performance, 10 , 85-97. http://dx.doi.org/10.1207/s15327043hup1002 2

Organ, D. W., \& Ryan, K. (1995). A Meta-Analytic Review of Attitudinal and Dispositional Predictors of Organizational Citizenship Behavior. Personnel Psychology, 48, 775-802. http://dx.doi.org/10.1111/j.1744-6570.1995.tb01781.x

Özdamar, K. (2001). Paket Programlarve İstatistiksel Veri Analizi (Çok Değişkenli Analizler) (4. Baskı). Eskişehir: Kaan Yayınları.

Özdevecioğlu, M. (2003). Örgütsel Vatandaşlık Davranışıile Üniversite Öğrencilerinin Bazı Demografik Özelliklerive Akademik Başarıları Arasındaki İlişkilerin Belirlenmesine Yönelik Bir Araştırma. Erciyes Üniversitesi İktisadive İdari Bilimler Fakültesi Dergisi, 20, 117-135.

Özyer, K., Orhan, U., \& Dönmez Orhan, D. (2012). Demografik Özelliklerin Örgütsel Vatandaşlık Davranışının Alt Boyutları İle İlişkisi: Bankacılık Sektöründe Bir Uygulama. Dokuz Eylül Üniversitesi İktisadive İdari Bilimler Fakültesi Dergisi, 27, 181-204.

Podsakoff, P. M., MacKenzie, S. B., Moorman, H. R., \& Fetter, R. (1990). Transformational Leader Behaviors and Their Effects on Followers' Trust in Leader, Satisfaction, and Organizational Citizenship Behaviors. Leadership Quarterly, 1, 107-142. http://dx.doi.org/10.1016/1048-9843(90)90009-7

Podsakoff, P. M., Mackenzie, S. B., Paine, J. B., \& Bachrach, D. G. (2000). Organizational Citizenship Behaviors: A Critical Review of the Theoretical and Empirical Literature and Suggestions for Future Research. Journal of Management, 26, 513-563. http://dx.doi.org/10.1177/014920630002600307

Schappe, S. P. (1998). The Influence of Job Satisfaction, Organizational Commitment, and Fairness Perceptions on Organizational Citizenship Behavior. The Journal of Psychology, 132, 277-290. http://dx.doi.org/10.1080/00223989809599167

Schermelleh-Engel, K., \& Moosbrugger, H. (2003). Evaluating the Fit of Structural Equation Models: Test of Significance and Descriptive Goodness-of-Fit Measures. Methods of Psychological Research Online, 8, 23-74. 
Sezgin, F. (2005). Örgütsel Vatandaşlık Davranışları: Kavramsal Bir Çözümlemeve Okul Açısından Bazı Çıkarımlar. Gazi Ĕ̈itim Fakültesi Dergisi, 25, 317-339.

Sökmen, A., \& Boylu, Y. (2011). Örgütsel Vatandaşlık Davranış1 Cinsiyete Göre Farklılık Gösterir Mi? Otel İşletmeleri Açısından Bir Değerlendirme. Gaziantep Üniversitesi Sosyal Bilimler Dergisi, 10, 147-163. http://sbe.gantep.edu.tr

Sümer, N. (2000). Yapısal Eşitlik Modelleri Temel Kavramlar Ve Örnek Uygulama. Türk Psikoloji Yazıları, 3, 49-73.

Şahin, A., Cankurt, M., Günden, C., \& Vemiran, B. (2008). Çiftçilerin Risk Davranışları: Bir Yapısal Eşitlik Modeli Uygulamas1. Dokuzeylül Üniversitesi Iktisadi VeIdari Bilimler Fakültesi Dergisi, 23, 153-172.

Şehribanoğlu, S. (2005). Yapısal Eşitlik Modellerive Bir Uygulama. Yüksek Lisans Tezi, Yüzüncü Yıl Üniversitesi, Fen Bilimleri Enstitüsü, Van.

Taşç1, D., \& Koç, U. (2007). Örgütsel Vatandaşlık Davranış1-Örgütsel Öğrenme Değerleri İlişkisi: Akademisyenler Üzerinde Görgül Bir Araştırma. Anadolu Üniversitesi Sosyal Bilimler Dergisi, 7, 373-382.

Türk Dil Kurumu (2014). Türk Dil Kurumu, Güncel Türkçe Sözlük. http://www.tdk.gov.tr/index.php?option=com gts\&arama=gts\&guid=TDK.GTS.547ca874186493.00688254

Ünüvar, T. G. (2006). An Integrative Model of Job Characteristics, Job Satisfaction, Organizational Commitment, Andorganizational Citizenship Behavior. Ankara: Ortadoğu Teknik Üniversitesi, Sosyal Bilimler Enstitüsü, Yayımlanmamış Yüksek LisansTezi.

Vey, M. A., \& Campbell, J. P. (2004). In-Role or Extra-Role Organizational Citizenship Behavior: Which Are We Measuring? Human Performance, 17, 119-135. http://dx.doi.org/10.1207/S15327043HUP1701_6

Yeşiltaş, M., \& Keleş, Y. (2009). İşgörenlerine Eğitim Düzeyleri ve Örgütsel Vatandaşlık Davranışları Arasındaki Ilişkinin Incelenmesine Yönelik Bir Araştırma. Gazi Üniversitesi İktisadive İdari Bilimler Fakültesi Dergisi, 11, 17-40.

Yılmaz, V., \& Çelik, H. E. (2005). Bankacılık Sektöründe Müşteri Memnuniyetive BankayaBağlılıkArasındakilllişkininYapısalEşitlik Modeli İle Araştırılması., VII. Ulusal Ekonometrive İstatistik Sempozyumu, İstanbul Üniversitesi.

Waris, R. G. (2005). An Examination of Organizational Culture, Employee Attitudes, and Organizational Citizenship Behaviors: A Path Analysis Approach. Kansas City: Umi.

Willıams, S., \& Shıw, W. T. (1999). Mood and Organizational Citizenship Behavior: The Effects of Positive Affect on Employee Organizational Citizenship Behavior Intentions. The Journal of Psychology, 133, 656-668. http://dx.doi.org/10.1080/00223989909599771 